\title{
Cutis marmorata telangiectatica congenita: a mimicker of a common disorder
}

\author{
Rebecca Levy MD, Joseph M. Lam MD
}

A three-month-old girl presented with a reticular erythematous patch over her right thigh, which had been present since birth. The lesion did not disappear with warming. Her parents had also noticed a discrepancy in the size of her lower limbs, with relative atrophy of the right thigh. Aside from dermal melanocytosis (patches of hyperpigmentation), cutaneous lesions were absent from other areas of the skin, including the head and neck region. The infant had not been given any medications, had no known allergies and was otherwise well. Her past medical history was unremarkable, aside from a persistent right umbilical vein detected in utero. Her growth and development were normal. There was no family history of vascular malformations.

On examination, the infant appeared well and was in no apparent distress. Her head circumference was at the 50th percentile. Results of a neurologic examination were grossly normal. Dermatologic examination revealed a reticular erythematous patch extending from the right inguinal area to the midsection of her right shin (Figure 1). Subtle cutaneous atrophy was noted. The right thigh was smaller in girth than the left. The length of her lower limbs, measured from the anterior superior ileac spine to the medial malleolus, did not differ. The Galeazzi sign (flexing the hips and knees while the patient is supine to reveal a discrepancy in femur length) showed symmetrical knee height.

The infant was diagnosed with a congenital vascular malformation known as cutis marmorata telangiectatica congenita.

\section{Discussion}

Cutis marmorata telangiectatica congenita is characterized by reticular erythema that is either generalized over the entire body or localized to a specific area or limb. When localized, the lesion tends to remain unilateral and not cross the midline, and it may be sharply demarcated. The colour of the lesion can range from deep violet to red. Although generally recognized as a sporadic condition, case reports of familial associations have suggested a possible genetic link. ${ }^{1}$

\section{Clinical significance}

Cutis marmorata telangiectatica congenita is a relatively uncommon condition, with about 300 cases described in the literature to date. ${ }^{2}$ The condition closely resembles cutis marmorata, a common, benign reticular mottling of the skin seen in small children that is due to physiologic dilatation of capillaries and small venules in response to cold. Important differences exist between the congenital condition and physiologic cutis marmorata that can help to distinguish between these lesions. Although cutis marmorata disappears with local warming, the congenital condition will persist despite increases in ambient temperature. ${ }^{1}$ Furthermore, cutis marmorata telangiectatica congenita is associated with several cutaneous and extracutaneous findings, which further exemplifies the importance of accurate diagnosis.

\section{Cutaneous findings}

The pattern of the lesion in cutis marmorata telangiectatica congenita may include prominent veins, telangiectasias, cutaneous atrophy, ulceration and hyperkeratosis. The presence of atrophy or skin ulceration can be particularly useful in
Competing interests: None declared.

This article has been peer reviewed.

Correspondence to: Dr. Joseph M. Lam, joseph.mc.lam@gmail.com

CMAJ 2011. DOI:10.1503 /cmaj.091749

\section{- Ker poInTs}

- Cutis marmorata telangiectatica congenita is a relatively uncommon disorder that can mimic cutis marmorata, a common benign physiologic response to cold in infants.

- Unlike cutis marmorata, it does not disappear with warming.

- Patients with cutis marmorata telangiectatica congenita should be evaluated for associated anomalies, such as growth and developmental delays, discrepancies in the length and girth of limbs, and ocular abnormalities if facial lesions are present.

- Head circumference should be measured to rule out more serious conditions. 
distinguishing between the congenital and physiologic conditions. Atrophy and skin ulceration are common features of cutis marmorata telangiectatica congenita, but they should not be present with cutis marmorata. ${ }^{1}$ Furthermore, the presence of sharp demarcation of a localized lesion favours a diagnosis of the congenital condition over cutis marmorata, which appears more mottled and has ill-defined borders.

\section{Extracutaneous findings}

Associated anomalies have been reported in $20 \%$ to $80 \%$ of patients with cutis marmorata telangiectatica congenita. ${ }^{1,2}$ Controversy surrounds these rates, because the reports may have included patients with distinct genetic disorders, including macrocephaly-capillary malformation. The rates may also be overestimated because

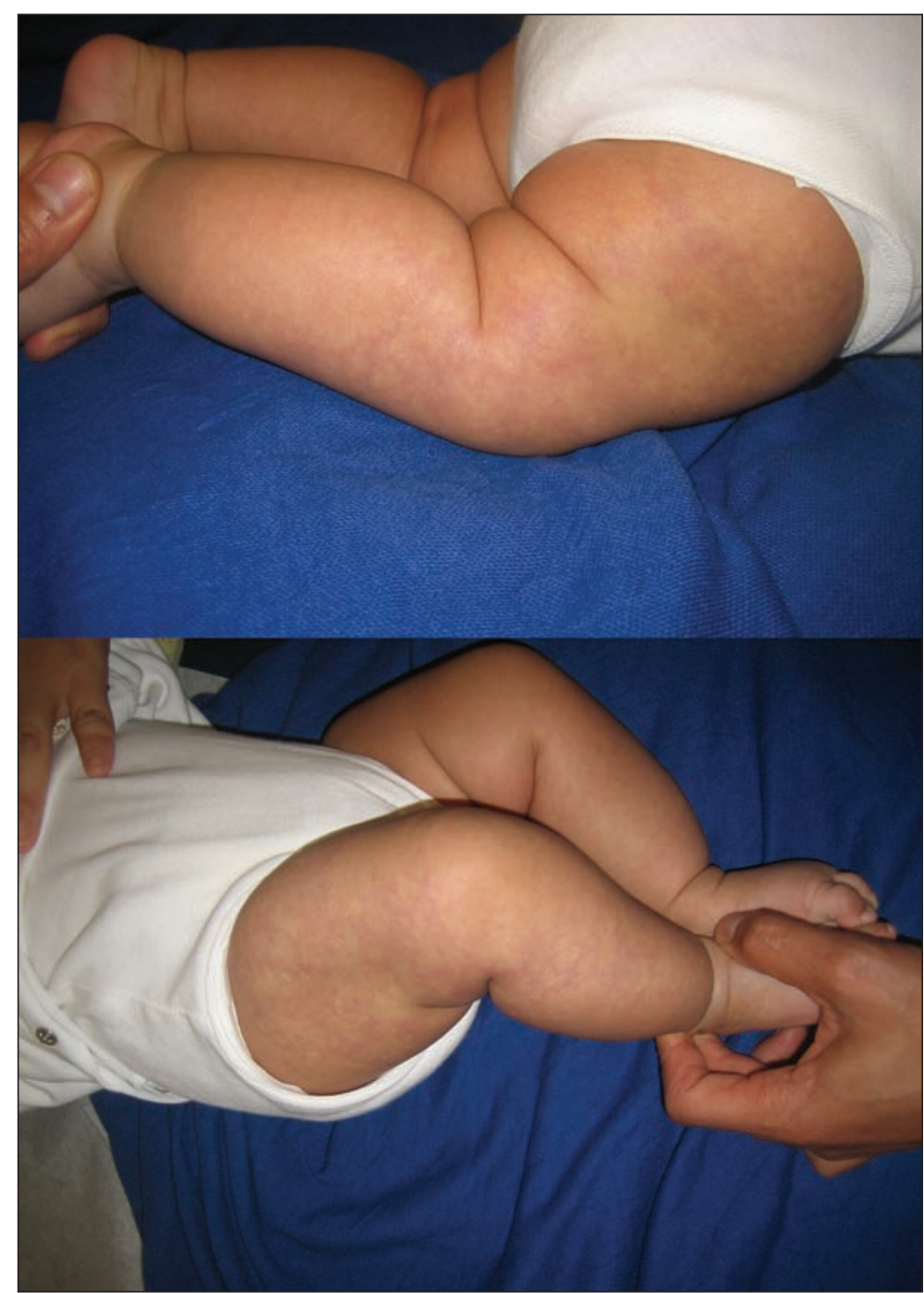

Figure 1: A reticular erythematous patch and subtle cutaneous atrophy over the right thigh extending to the midsection of the shin, consistent with cutis marmorata telangiectatica congenita, in a three-month-old girl. some "associated" findings could presumably be coincidental. It is unclear whether the severity or extent of a lesion in cutis marmorata telangiectatica congenita correlates with the presence of associated anomalies.'

Asymmetry, particularly of the limbs, is the most common extracutaneous finding in cutis marmorata telangiectatica congenita. The affected limb may be either atrophied or hypertrophied, and overlying cutaneous atrophy is frequently present. Other skeletal defects have been reported, including syndactyly, tendinitis stenosans, hip dysplasia, clubfoot and cleft palate. ${ }^{1}$ A detailed musculoskeletal examination on presentation will help to determine if any of these defects are present.

Ocular abnormalities, particularly glaucoma, have been reported in patients with facial lesions associated with cutis marmorata telangiectatica congenita. ${ }^{1}$ Based on our clinical experience, we recommend ophthalmologic investigation in all patients with facial involvement.

Additional vascular anomalies have been described both overlying and distant to the lesion. Of these anomalies, port-wine stains were reported most frequently. ${ }^{3}$ However, reticular port-wine stain remains high on the differential diagnosis for cutis marmorata telangiectatica congenita and could easily be misdiagnosed, as discussed further in the section on the differential diagnosis. ${ }^{1}$ Other vascular anomalies associated with cutis marmorata telangiectatica congenita include angiokeratomas and hemangiomas.

Neurologic abnormalities have been reported in association with cutis marmorata telangiectatica congenita. A high frequency of concomitant macrocephaly led to the designation of a distinct subtype of the condition called macrocephalycutis marmorata telangiectasia congenita in 1997. ${ }^{4}$ In addition to macrocephaly and cutis marmorata telangiectatica congenita, the syndrome consists of neonatal hypotonia, developmental delay, segmental overgrowth, syndactyly, asymmetry and connective-tissue defects. ${ }^{4}$ More recently, the literature has suggested that "macrocephaly-cutis marmorata telangiectasia congenita" is actually a distinct condition and should be renamed macrocephaly-capillary malformation, because the skin findings are likely more consistent with capillary malformations rather than true cutis marmorata telangiectatica congenita. ${ }^{4,5}$ Regardless, we believe that physicians need to screen for developmental delay and measure the head circumference of all children presenting with any reticular erythematous lesion to rule out macrocephaly-capillary malformation. 
Box 1: Differential diagnosis of cutis marmorata telangiectatica congenita ${ }^{1,2}$

- Physiologic cutis marmorata

- Persistent cutis marmorata (especially in children with Down syndrome, de Lange syndrome, homocystinuria and Divry-Van Bogaert syndrome)

- Reticular capillary malformation (port-wine stain)

- Bockenheimer syndrome

- Neonatal lupus erythematous

- Macrocephaly-capillary malformation

- Adams-Oliver syndrome

- Phakomatosis pigmentovascularis with cutis marmorata telangiectatica congenita

- Klippel-Trénaunay syndrome

\section{Differential diagnosis}

For accurate diagnosis of cutis marmorata telangiectatica congenita, several disorders must be ruled out (Box 1). This can generally be accomplished by thorough screening for associated anomalies. The most common lesion presenting with a reticular erythematous patch is cutis marmorata. Although it is most often physiologic and resolves in early childhood, it may be persistent, particularly in children with Down syndrome, de Lange syndrome, homocystinuria and Divry-Van Bogaert syndrome. ${ }^{1}$ Bockenheimer syndrome is a diffuse phlebectasia that presents in early infancy and results in progressive venous ectasias that are often large and painful. ${ }^{2}$ Adams-Oliver syndrome can present as generalized cutis marmorata telangiectatica congenita associated with cardiac malformations, limb defects, and abnormalities of the scalp and cranium. ${ }^{1}$ Klippel-Trénaunay syndrome consists of vascular malformations associated with venectasia and soft-tissue hypertrophy. ${ }^{2}$

Capillary malformations, such as port-wine stains, can present in a reticular pattern, which makes it difficult to distinguish between these disorders and cutis marmorata telangiectatica congenita. Both may be localized and unilateral, without crossing the midline. Unlike port-wine stains, however, cutis marmorata telangiectatica congenita tends to partially fade in colour with time, often within the first two years of life, which allows for an accurate retrospective diagnosis. Furthermore, port-wine stains may have more distinct borders and are not associated with underlying atrophy. ${ }^{1}$

Kienast and Hoeger ${ }^{2}$ recently proposed a set of criteria for the diagnosis of cutis marmorata telangiectatica congenita (Box 2). They have suggested that the presence of all three major criteria in addition to two minor criteria is suffi-
Box 2: Proposed diagnostic criteria for cutis marmorata telangiectatica congenita*2

The presence of all three major criteria

- Congenital reticular (marmorated) erythema

- Absence of venectasia

- Unresponsiveness to local warming

The presence of two or more minor criteria

- Fading of erythema within two years

- Telangiectasia within affected area

- Port-wine stain

- Ulceration within affected area

- Atrophy within affected area

*These criteria have not been evaluated for diagnostic validity.

cient for diagnosis. However, the validity of these criteria has not been established, and the authors have suggested further investigation for this purpose. ${ }^{2}$

\section{Monitoring}

Based on our review of the literature, once cutis marmorata telangiectatica congenita has been diagnosed and an initial screen for associated anomalies has been done, we suggest that patients be seen annually for a minimum of three years. Follow-up visits should include continued screening for associated anomalies and further attempts to rule out the conditions that may initially mimic cutis marmorata telangiectatica congenita. ${ }^{2} \mathrm{Al}-$ though the vascular lesion often lightens with time, the limb asymmetry tends to persist. ${ }^{1}$

\section{References}

1. Garzon MC, Schweiger E. Cutis marmorata telangiectatica congenita. Semin Cutan Med Surg 2004;23:99-106.

2. Kienast AK, Hoeger PH. Cutis marmorata telangiectatica congenita: a prospective study of 27 cases and review of the literature with proposal of diagnostic criteria. Clin Exp Dermatol 2009;34:319-23.

3. Amitai DB, Fichman S, Merlob P, et al. Cutis marmorata telangiectatica congenita: clinical findings in 85 patients. Pediatr Dermatol 2000;17:100-4.

4. Gonzalez ME, Burk CJ, Barbouth DS, et al. Macrocephalycapillary malformation: a report of three cases and review of the literature. Pediatr Dermatol 2009;26:342-6.

5. Wright DR, Frieden IJ, Orlow SJ, et al. The misnomer "macrocephaly-cutis marmorata telangiectatica congenital syndrome": report of 12 new cases and support for revising the name to macrocephaly-capillary malformations. Arch Dermatol 2009;145:287-93.

Affiliations: From the Department of Paediatrics (Levy), The Hospital for Sick Children, University of Toronto, Toronto, Ont.; and the Departments of Pediatrics and Dermatology (Lam), University of British Columbia, Vancouver, BC

Contributors: Both authors contributed substantially to the drafting of the article, revised it critically for important intellectual content and approved the final version submitted for publication. 